\title{
Gorolski Święto w XX w.
}

opracowanie:

\section{LEOKADIA DROŻDŻ}

Państwowy Instytut Naukowy - Instytut Śląski w Opolu

\section{ROCZNIK}

\section{ZIEM}

\section{ZACHODNICH}

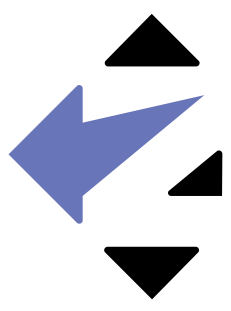


Święto Góralskie to największy polski festiwal kulturalno-folklorystyczny na Zaolziu. Po zakończeniu II wojny światowej idea wznowienia festynów została zainicjowana przez grupę polskich aktywistów z Zaolzia. Decyzję o zorganizowaniu pierwszego festynu podjęto 30 czerwca 1948 r. na zebraniu Miejscowego Koła Polskiego Związku Kulturalno-Oświatowego (MK PZKO) w Jabłonkowie. Termin imprezy wyznaczono na 5 sierpnia tegoż roku. Na kolejnym zebraniu, 22 lipca 1948 r., festyn ten na wniosek malarza i pisarza Karola Piegzy (1899-1988) nazwano Świętem Góralskim. Jeszcze dwukrotnie zmieniano datę pierwszego Święta Góralskiego, ostatecznie odbyło się ono 12 września 1948 r. ${ }^{1}$ Postanowiono zaprosić zespoły z okolicznych gmin i nadać imprezie charakter ludowy. Pierwsze święto odbyło się w Lasku Miejskim w Jabłonkowie i było tak dużym sukcesem, że postanowiono kontynuować je corocznie na początku sierpnia. Początkowo impreza miała charakter festynu, a z czasem przybrała formę międzynarodowego festiwalu folklorystycznego.

Od 1952 do 1962 r. Święto Góralskie odbywało się na byłym boisku sportowym w Jabłonkowie, w Szygle². Początkowo występowały tu tylko zespoły miejscowe, w 1955 r. pojawiły się zespoły z Moraw i ze Słowacji, z roku na rok dołączali do wspólnej zabawy reprezentanci z innych krajów ${ }^{3}$. Odtąd do 1961 r. organizacją tegoż święta zajmował się powstały przy Miejscowym Kole PZKO w Jabłonkowie chór męski Gorol. Występ tego zespołu był głównym punktem programu Gorolskiego Święta. Oprócz chóru można było usłyszeć i zobaczyć popisy gawędziarskie i narratorskie członków zespołu. Dzięki temu wyłoniły się indywidualności, które stały się „ozdobą" zespołu. W pierwszych latach taką postacią był gawędziarz „Michoł” - Alojzy Ligocki, a po nim popularny wiejski jąkała „Maciej” (Ludwik Cienciała, 1922-1984) oraz „Jura spod Grónia” (Władysław Niedoba, 1914-1999), to ich nie mogło zabraknąć na żadnym Święcie Góralskim. W latach 70. XX w. dołączył do nich „Hadam z drugi jizby” (Władysław Młynek, 1930-1997), a w 1990 r. „Filip” (Tadeusz Filipczyk), który towarzyszy zespołowi do dziś.

Z czasem brzmienie nazwy Święto Góralskie dostosowano do wymowy dialektu cieszyńskiego Gorolski Święto i taka nazwa używana jest od 1967 r. do dzisiaj ${ }^{4}$. W skrócie mówi się o nim także "Gorol”. W miarę upływu czasu zaczęła się kształtować nowa forma obchodów Gorolskiego Święta, obejmująca wspólne występy połączonych chórów: Gorola z Jabłonkowa, Melodii z Nawsia, później Przełęczy z Mostów k. Jabłonkowa. Do wspólnie wykonywanych pieśni przygrywała orkiestra dęta Huty Trzynieckiej.

150 Gorolski Święto i Zespół MK PZKO Jabłonków Gorol obchodzi swe pięćdziesięciolecie, red. J. Cieńciała, W. Młynek, A. Szpryc, B. Słowiaczek, Jabłonków 1997, s. 16.

2 Historia 30 Świat Gorola, oprac. K. Piegza, G. Słowik, Jabłonków 1977, s. 14

3 Na Święcie Góralskim zobaczymy zespoły polskie, czeskie i węgierskie. Kronika, „Zwrot”, R. XII (1960), nr 6, s. 10 . 
W roku 1990, z inicjatywy W. Młynka, doszło do połączenia Gorolskiego Święta z Tygodniem Kultury Beskidzkiej. Umożliwiło to zaprezentowanie publiczności zespołów ludowych z całego świata ${ }^{5}$.

W 1982 r. zorganizowano po raz pierwszy wystawę pt. „Beskidy w rzeźbie i malarstwie". Była to akcja towarzysząca Gorolskiemu Świętu. Odtąd kolejne edycje wystawy organizowane są każdego roku - pierwotnie w Domu PZKO, w szkole, na Harcowie, a w ostatnich latach w Domu Działkowca w Jabłonkowie. Zajmuje się tym Klub Twórców Ludowych przy Zarządzie Głównym PZKO.

Oprócz prezentacji rodzimej twórczości, Klub Twórców Ludowych zorganizował w 1988 r. wystawę koronek koniakowskich oraz kowalstwa ludowego i rzeźby ludowej z rejonu Istebnej, Koniakowa i Jaworzynki. W następnym roku zaprezentowano twórczość grupy plastycznej Brzimy z Wisły. W roku 1991 wystawiane były stare fotografie Karola Piegzy i fotografa bystrzyckiego Karola Kalety (1906-1998), przedstawiające życie górali beskidzkich w okresie międzywojennym. Rok później zorganizowano wystawę strojów ludowych Śląska Cieszyńskiego, zaś w 1993 r. - wystawę rysunków tuszem Władysława Benczyka z Nawsia. Artysta zaprezentował zwiedzającym urok dawnej architektury drewnianej Podbeskidzia i dawnego Jabłonkowa. W roku 1994 uczestnicy Gorolskiego Święta mogli zapoznać się z wystawą pt. Nasz region, na którą złożyły się rysunki uczniów polskich i czeskich szkół z Piosku, Bukowca, Herczawy, Istebnej, Koniakowa i Jaworzynki.

Z okazji jubileuszowego 50. Gorolskiego Święta w 1997 r. zaprezentowano wystawę retrospektywną poświęconą historii Gorolskich Świąt. Eksponowane były wówczas materiały archiwalne, których autorem był Karol Piegza, jeden z założycieli święta górali jabłonkowskich.

Corocznie w niedzielę w południe wyrusza pochód do Lasku Miejskiego. Na czele pochodu od 1951 r. jechał na koniu „Jura spod Grónia” Władysław Niedoba, za nim kroczył poczet sztandarowy, goście, zespoły uczestniczące w święcie, kapele i wozy alegoryczne poszczególnych kół $\mathrm{PZKO}^{6}$. Obecnie pochód na siwku rozpoczyna Adam Ryłko. Barwny, roztańczony i rozśpiewany pochód był i jest stałym elementem Gorolskigo Święta.

Tradycyjną częścią pochodów są wozy alegoryczne; pierwszym był wóz z Nawsia. Przedstawiono na nim starą góralską chatę krytą słomą, przed nią stary góral szył kierpce, pasterz mielił zboże na mąkę na żarnach, gaździna przędła na kołowrotku i huśtała dziecko w kołysce. Wozy alegoryczne obrazują sceny z różnych dziedzin życia górali, a więc jest tam budownictwo, tradycyjne zajęcia góralskie, obrzędowość związana z dorocznymi świętami. Z czasem zaczęto organizować konkursy na najpiękniejszy i najbardziej pomysłowy wóz alegoryczny? 
Innym punktem programu jest degustacja potraw regionalnych. Na pierwszych Gorolskich Świętach stoiska do sprzedaży posiłków były bardzo proste, częstokroć pojawiał się tylko stół, z czasem poszczególne miejscowe koła PZKO zaczęły budować przenośne stoiska. Wymagano, by każde z nich było podobne do szopy lub kolyby (szałasu) góralskiej. Od połowy lat 70. XX w. zaczęto konstruować stoiska stałe, do MK PZKO dołączyły również inne organizacje społeczne.

Każde z kół PZKO przygotowuje się do Gorolskiego Święta, które w ciągu kilku dni aktywizuje kilkuset społeczników bezinteresownie działających na rzecz własnego koła lub organizacji. W Lasku Miejskim prezentują się oni i oferują specjały kuchni. Można tam podelektować się kołaczami z borówkami, serem lub makiem, „kiszką" (kaszanką), plackami „na blaszi” (ziemniaczanymi), do potraw podawane są swojskie nalewki: warzónka, tatarczok, śliwówka, miodula i inne ${ }^{8}$.

Od 1984 r. towarzyszy Gorolskiemu Świętu sportowy „Bieg o dzbanek mleka”, którego trasa wiedzie w okolicy Lasku Miejskiego. Odbywa się on w niedzielne przedpołudnie, a podzielony jest na kategorie i co roku uczestniczy w nim kilkadziesiąt osób. Od 1993 r. organizowany jest również rajd turystyczny „O kyrpce Macieja” z nagrodą dla najstarszego i najmłodszego turysty.

Gorolski Święto swym zakresem i ofertą programową przerosło region zaolziański, jest znanym w Europie folklorystycznym festiwalem. Folklor wzbogaca kulturę ogólnonarodową, a nawet światową o lokalny koloryt, o treści głęboko tkwiące w pokładach kultury ludowej, a więc najbardziej autentycznej, zrodzonej z doświadczenia i poczucia piękna wielu pokoleń. Regionalizm zaś jest nurtem, który uczy przywiązania do ziemi rodzinnej, pobudza inicjatywę, aktywizuje do działania, do przerzucania mostów między dawnym wczoraj a bliskim jutrem w imię piękna i celowości życia9.

Na Gorolski Święto przyjeżdża mnóstwo ludzi, którzy traktują je jako okazję do spotkań z przyjaciółmi, kolegami, znajomymi, zwłaszcza z tymi, z którymi widują się bardzo rzadko. Ważne jest także to, że czuje się tu niespotykaną atmosferę rodzimej spójności, co sprawia również otoczenie, środowisko: las, Olza, świeże powietrze, otwarta przestrzeń i zieleń ${ }^{10}$.

Jak napisał z okazji jubileuszu 30-lecia Gorolskiego Święta Daniel Kadłubiec:

Dzięki pracy Jury spod Grónia i wielu bezimiennych, lecz wszystkich społeczników powstało niezniszczalne Gorolskie Święto, bo niezniszczalna jest kultura, która staje się sensem. Dzięki niemu kultura ta nie jest zabytkiem, nie jest tylko echem przeszłości, ale żywą wartością [...], ciągłości i tożsamości jako jednego z zasadniczych warunków zachowania samodzielnego bytu społecznego i narodowego ${ }^{11}$.

10 H. Jasiczek, Niedziela pachnqca żywicq. Nasza kolumna, „Zwrot”, R XVI (1964), nr 9, s. 4.

11 D. Kadłubiec, Sens i wartość naszego święta, [w:] 50 Gorolski Święto i Zespół MK PZKO Jabłonków Gorol obchodzi swe pięćdziesięciolecie, red. J. Cieńciała, W. Młynek, A. Szpryc, B. Słowiaczek, Jabłonków 1997, s. 12. 
Przedstawiane zdjęcia dotyczące Gorolskiego Święta znajdują się w Archiwum Związkowym Polskiego Związku Kulturalno-Oświatowego w Czeskim Cieszynie (AZ PZKO). Autorzy fotografii w większości nie są znani. Autorem zdjęć nr 5-6 jest Stanisław Orszulik, a zdjęcia nr 8 Czesław Góral.

\section{Bibliografia}

Drożdż L., Gorolski Święto i Święto Trzech Braci, [w:] Leksykon mitów, symboli i bohaterów Górnego Śląska XIX-XX wieku, red. B. Linek, A. Michalczyk, Opole 2015, s. 367-370

Drożdż L., „Góralu, czy ci nie żal...”, „Śląsk Opolski”, R. XIII (2003), nr 1, s. 48-49

Gorolski Święto, [w:] Leksykon PZKO, red. M. Radłowska-Obrudník, O. Toboła, Czeski Cieszyn 1997, s. $55-56$

Historia 30 Świq̨ Gorola, oprac. K. Piegza, G. Słowik, Jabłonków 1977

Ho! Ho! Ho! Na Gorola wio! Almanach na jubileuszowe 60. Gorolski Święto 1948-2007, Jabłonków 2007 Jasiczek H., Niedziela pachnq̨a żywica. Nasza kolumna, „Zwrot”, R XVI (1964), nr 9, s. 4-5

Kadłubiec D., Parę refleksji, „Zwrot”, R. LXII (2011), nr 8, s. 9-10

50 Gorolski Święto i Zespół MK PZKO Jabłonków Gorol obchodzi swe pięćdziesięciolecie, red. J. Cieńciała, W. Młynek, A. Szpyrc, B. Słowiaczek, Jabłonków 1997 
Fot. 1. Święto Góralskie, ok. 1950 r.

ARCHIWUM - Archiwum Związkowe Polskiego Związku Kulturalno-Oświatowego w Czeskim Cieszynie (dalej: AZ PZKO)

NUMER IDENTYFIKACYJNY - sygn. 324a-77a

NAZWA, TYTUŁ - Święto Góralskie

OPIS - Pochód podczas Święta Góralskiego, na koniu jedzie „Jura spod Grónia” - Władysław Niedoba (1914-1999), w tle zespoły folklorystyczne.

SŁOWA KLUCZOWE - Gorolski Święto, Święto Góralskie, Zaolzie, zespoły folklorystyczne TWORZYWO - papier fotograficzny

TECHNIKA- analogowy zapis obrazu

RODZAJ - fotografia analogowa czarno-biała

TWÓRCA - NN

MIEJSCE POWSTANIA - Jabłonków (Czechosłowacja, obecnie Republika Czeska)

CZAS POWSTANIA - [ok. 1950 r.]

WYMIARY - [11 x $17 \mathrm{~cm}]$

BIBLIOGRAFIA - brak

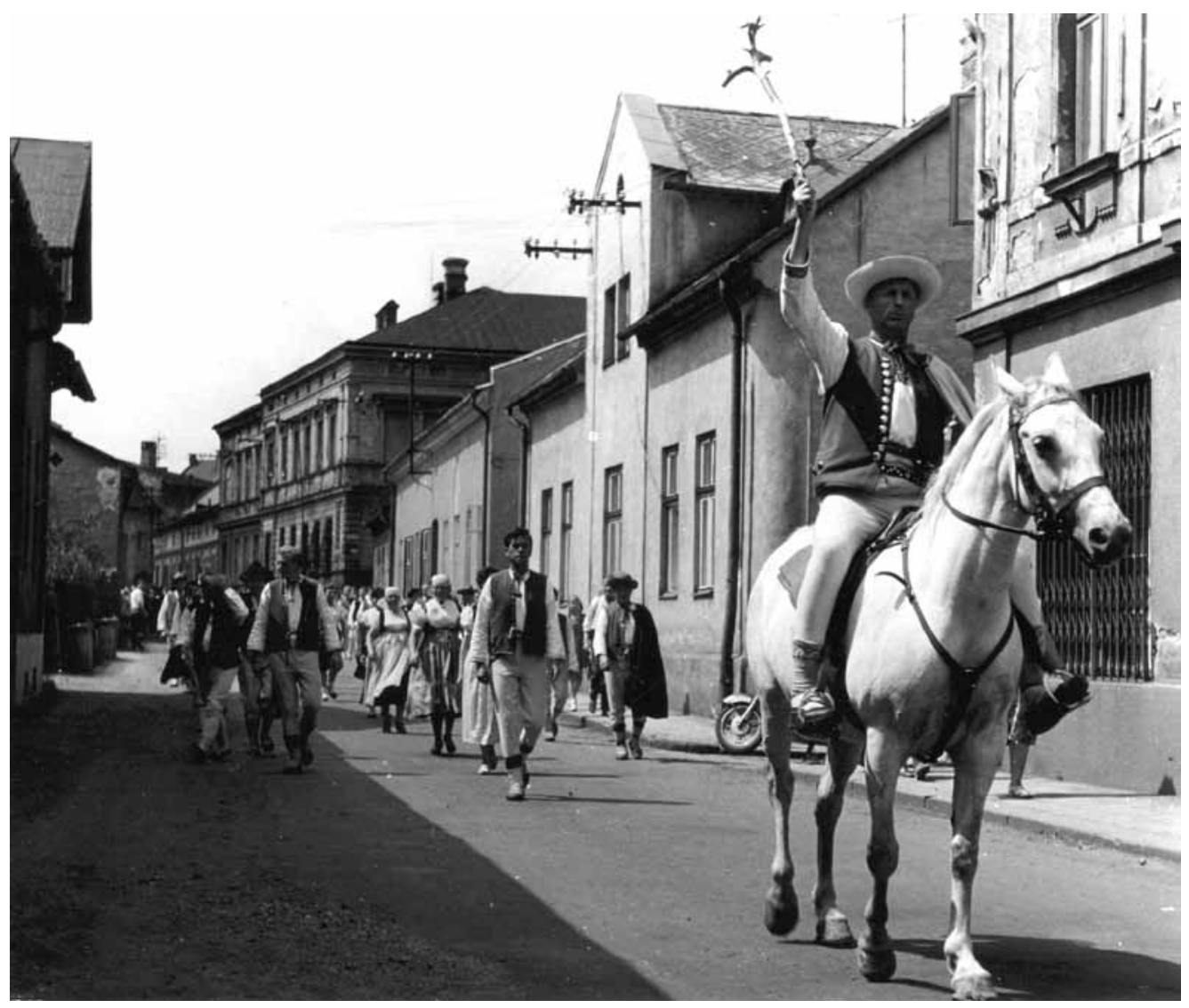


Fot. 2. Święto Góralskie, lata 50. XX w.

ARCHIWUM - AZ PZKO

NUMER IDENTYFIKACYJNY - sygn. 324a-77a

NAZWA, TYTUŁ - Święto Góralskie

OPIS - Pochód podczas Święta Góralskiego, w którym uczestniczą zespoły folklorystyczne, na czele pochodu członkowie chóru męskiego „Gorol” z Jabłonkowa niosą symbol Święta Góralskiego.

SŁOWA KLUCZOWE - Gorolski Święto, Święto Góralskie, Zaolzie, zespoły folklorystyczne

TWORZYWO - papier fotograficzny

TECHNIKA- analogowy zapis obrazu

RODZAJ - fotografia analogowa czarno-biała

TWÓRCA - NN

MIEJSCE POWSTANIA - Jabłonków droga na boisko w Szygle, miejsca, w którym w latach 19521960 odbywało się Święto Góralskie (Czechosłowacja, obecnie Republika Czeska)

CZAS POWSTANIA - [lata 50. XX w.]

WYMIARY - [10 x $15 \mathrm{~cm}]$

BIBLIOGRAFIA - brak

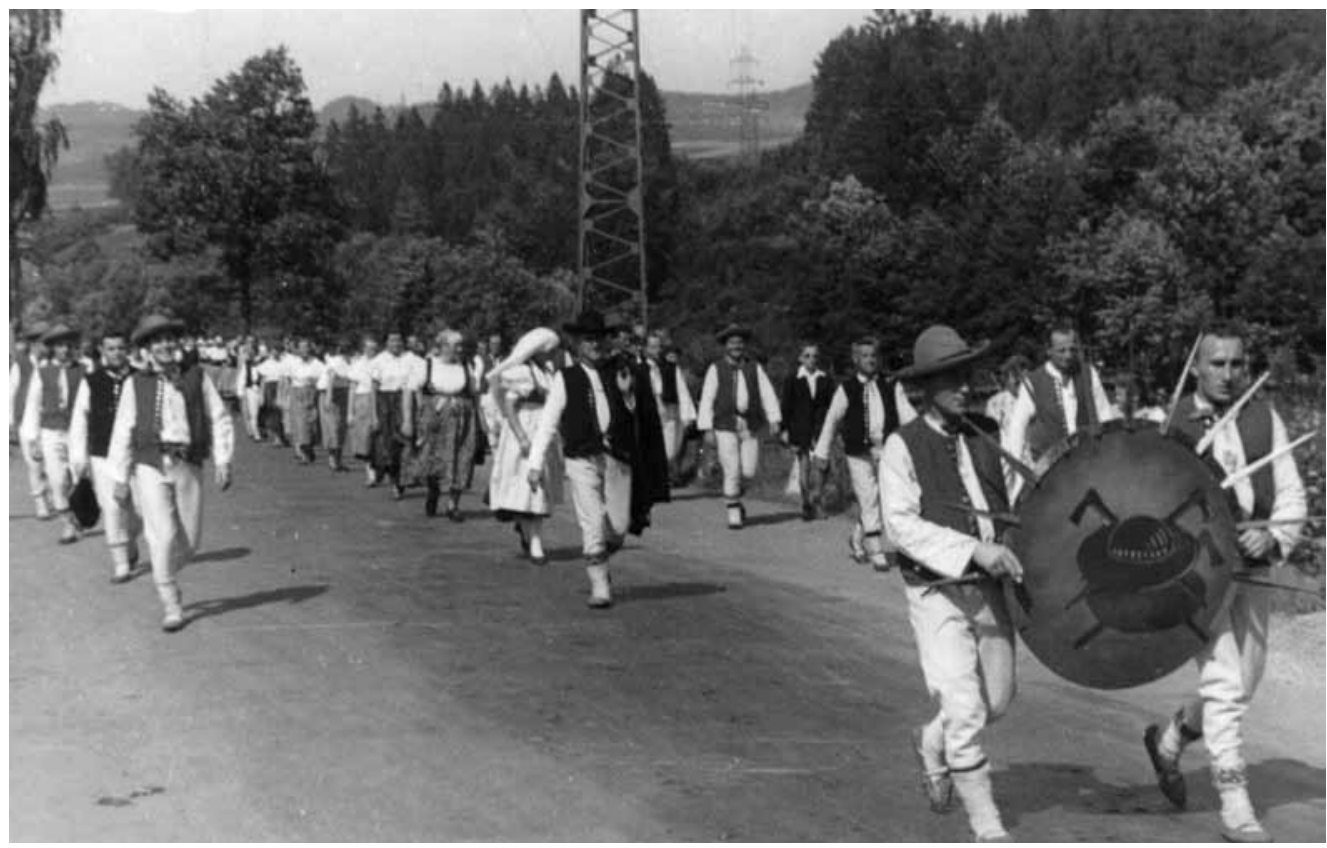


Fot. 3. Zespół Górnik, Święto Góralskie w Jabłonkowie, 1954 r.

\section{ARCHIWUM - AZ PZKO}

NUMER IDENTYFIKACYJNY - sygn. 324a-77a

NAZWA, TYTUŁ - Święto Góralskie

OPIS - Zespół „Górnik” z Karwiny w czasie pochodu na Święcie Góralskim, fragment pochodu SŁOWA KLUCZOWE - Gorolski Święto, Święto Góralskie, Zaolzie, zespoły folklorystyczne TWORZYWO - papier fotograficzny TECHNIKA- analogowy zapis obrazu RODZAJ - fotografia analogowa czarno-biała,

TWÓRCA - NN

MIEJSCE POWSTANIA - Jabłonków, droga na boisko w Szygle, miejsca, w którym w latach 19521960 odbywało się Święto Góralskiego (Czechosłowacja, obecnie Republika Czeska).

CZAS POWSTANIA - 15.08.1954

WYMIARY - [11 x $17 \mathrm{~cm}]$

BIBLIOGRAFIA - brak

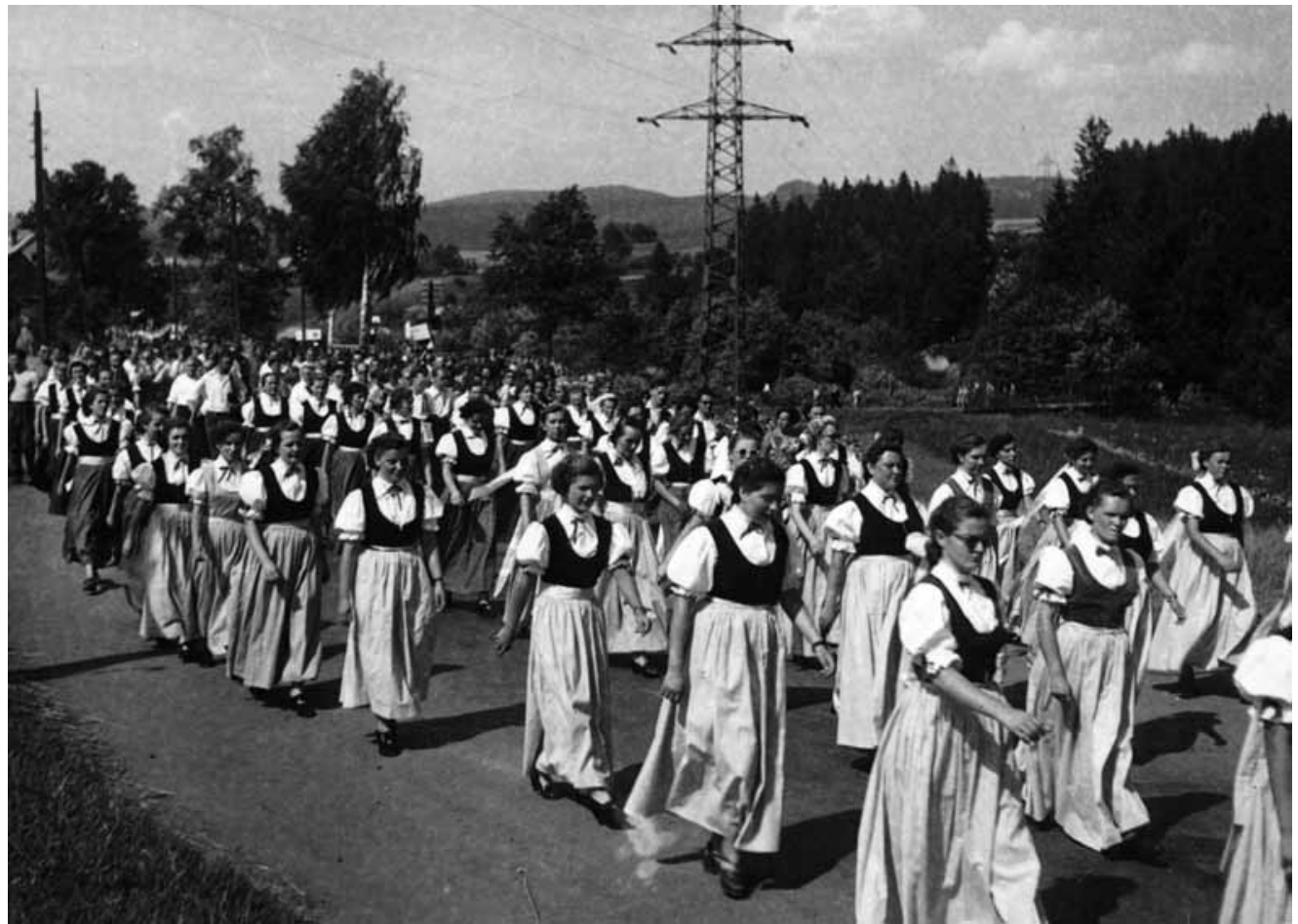


Fot. 4. 10. jubileuszowe Święto Góralskie, 18 VIII 1957 r.

\section{ARCHIWUM - AZ PZKO}

NUMER IDENTYFIKACYJNY - sygn. 324a-77a

NAZWA, TYTUŁ - Święto Góralskie

OPIS - 10. jubileuszowe Święto Góralskie, przy mikrofonie Władysław Niedoba w otoczeniu, chóru męskiego „Gorol”, zespołów folklorystycznych i orkiestry.

SŁOWA KLUCZOWE - Gorolski Święto, Święto Góralskie, Zaolzie, zespoły folklorystyczne TWORZYWO - papier fotograficzny

TECHNIKA- analogowy zapis obrazu

RODZAJ - fotografia analogowa czarno-biała

TWÓRCA - NN

MIEJSCE POWSTANIA - boisko w Szygle, miejsce, w którym w latach 1952-1960 odbywało się Święto Góralskie (Czechosłowacja, obecnie Republika Czeska)

CZAS POWSTANIA - 18.8.1957

WYMIARY - [13 x $18 \mathrm{~cm}]$

BIBLIOGRAFIA - Historia 30 Świąt Gorola, oprac. K. Piegza, G. Słowik, Jabłonków 1977, s. 26; Ho! Ho! Ho! Na Gorola wio! Almanach na jubileuszowe 60. Gorolski Święto 1948-2007, Jabłonków 2007, s. [8].

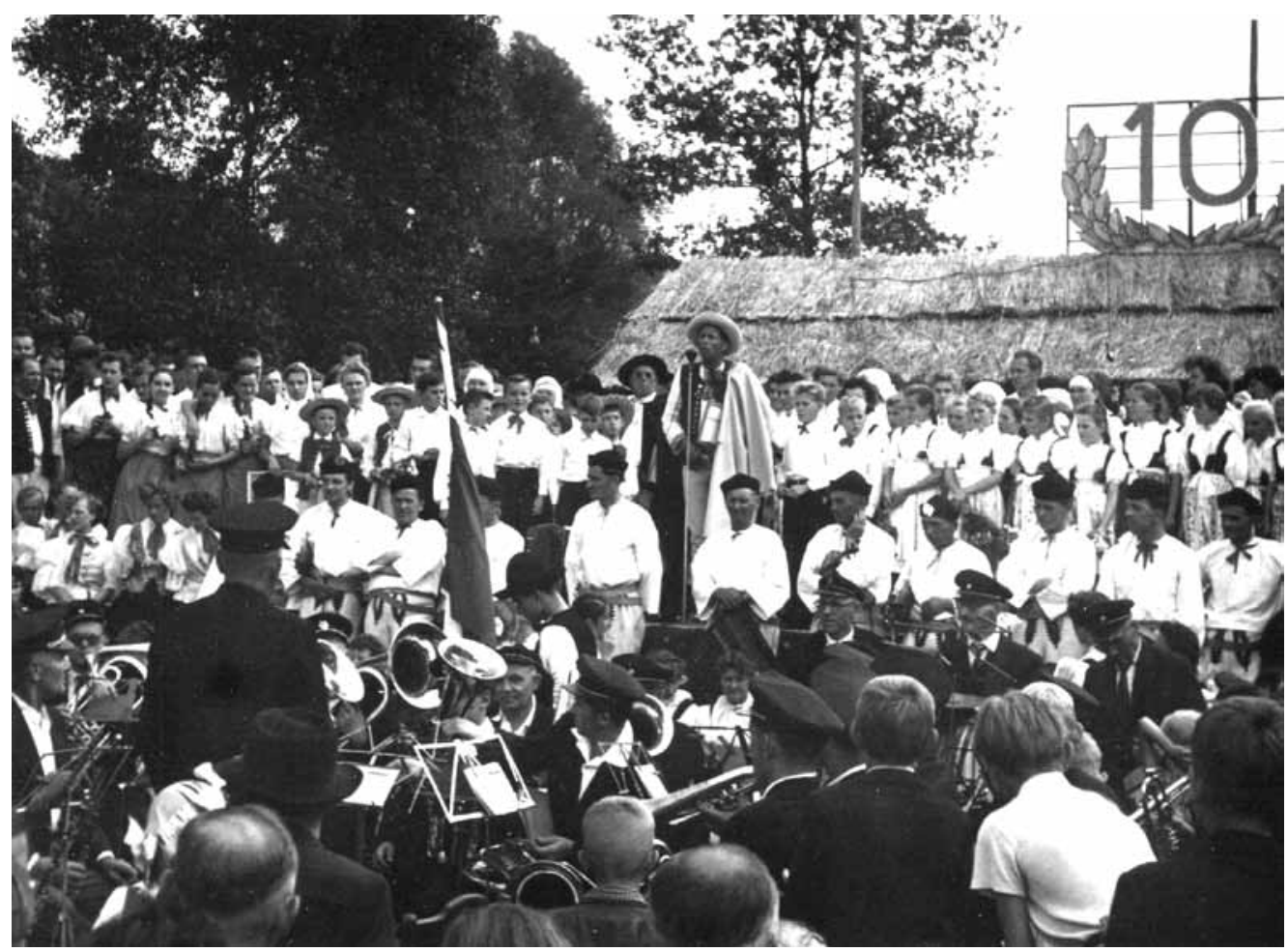


Fot. 5. Czołówka pochodu Gorolskiego Święta - rynek Jabłonków, 27 VII 1972 r.

\section{ARCHIWUM - AZ PZKO}

NUMER IDENTYFIKACYJNY - sygn. 324a-77a

NAZWA, TYTUŁ - Święto Góralskie

OPIS - Czołówka pochodu Gorolskiego Święta, na koniu - Władysław Niedoba, za nim członkowie zespołów folklorystycznych z flagami państwowymi.

SŁOWA KLUCZOWE - Gorolski Święto, Święto Góralskie, Zaolzie, zespoły folklorystyczne TWORZYWO - papier fotograficzny

TECHNIKA- analogowy zapis obrazu

RODZAJ - fotografia analogowa kolorowa,

TWÓRCA - Stanisław Orszulik

MIEJSCE POWSTANIA - Rynek w Jabłonkowie, miejsce, z którego wyrusza pochód Goroskiego Święta do Lasku Miejskiego (Czechosłowacja, obecnie Republika Czeska)

CZAS POWSTANIA - 27.7.1972

WYMIARY - [13 x $18 \mathrm{~cm}]$

BIBLIOGRAFIA - brak

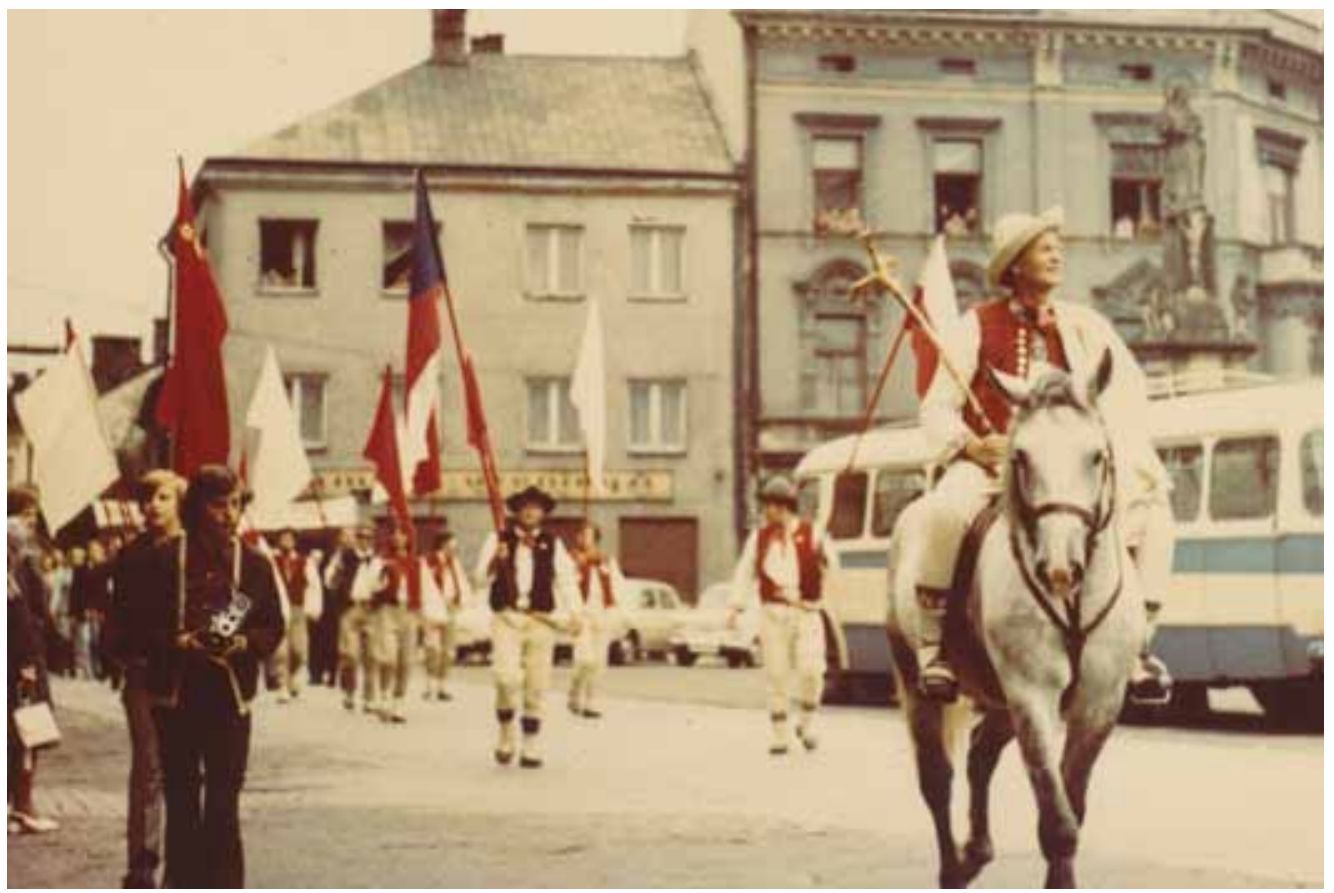




\section{ARCHIWUM - AZ PZKO}

NUMER IDENTYFIKACYJNY - sygn. 324a-77a

NAZWA, TYTUŁ - Święto Góralskie Jabłonków

OPIS - Wóz alegoryczny z Gródka podczas pochodu Gorolskiego Święta.

SŁOWA KLUCZOWE - Gorolski Święto, Święto Góralskie, Zaolzie, zespoły folklorystyczne TWORZYWO - papier fotograficzny

TECHNIKA - analogowy zapis obrazu

RODZAJ - fotografia analogowa kolorowa

TWÓRCA - Stanisław Orszulik

MIEJSCE POWSTANIA - Jabłonków droga do Lasku Miejskiego, miejsca, w którym odbywa się Święto Góralskie (Czechosłowacja, obecnie Republika Czeska)

CZAS POWSTANIA - 27.7.1972

WYMIARY - [13 x $18 \mathrm{~cm}]$

BIBLIOGRAFIA - brak

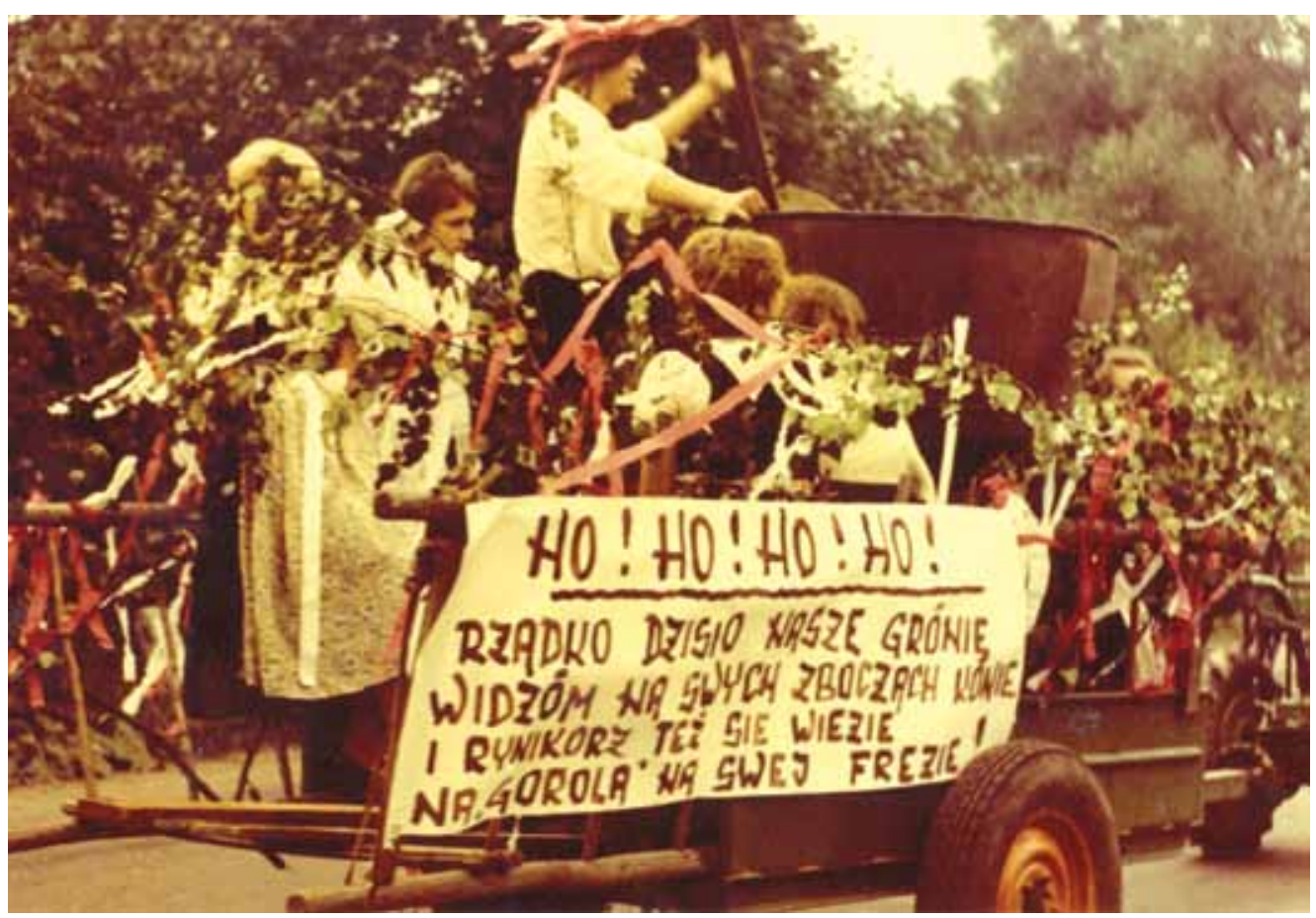


Fot. 7. Gorolski Święto - występy zespołów, 17 VIII 1975 r.

\section{ARCHIWUM - AZ PZKO}

NUMER IDENTYFIKACYJNY - sygn. 324a-77a

NAZWA, TYTUŁ - Święto Góralskie

OPIS - Zespół folklorystyczny podczas występu na scenie w Lasku Miejskim w Jabłonkowie w ramach Gorolskiego Święta.

SŁOWA KLUCZOWE - Gorolski Święto, Święto Góralskie, Zaolzie, zespoły folklorystyczne TWORZYWO - papier fotograficzny

TECHNIKA- analogowy zapis obrazu

RODZAJ - fotografia analogowa czarno-biała

TWÓRCA - Stanisław Gorolski

MIEJSCE POWSTANIA - Lasek Miejski w Jabłonkowie, miejsce, w którym odbywa się Gorolskie Święto (Czechosłowacja, obecnie Republika Czeska)

CZAS POWSTANIA - 17.8.1975

WYMIARY - [11 x $17 \mathrm{~cm}]$

BIBLIOGRAFIA - brak

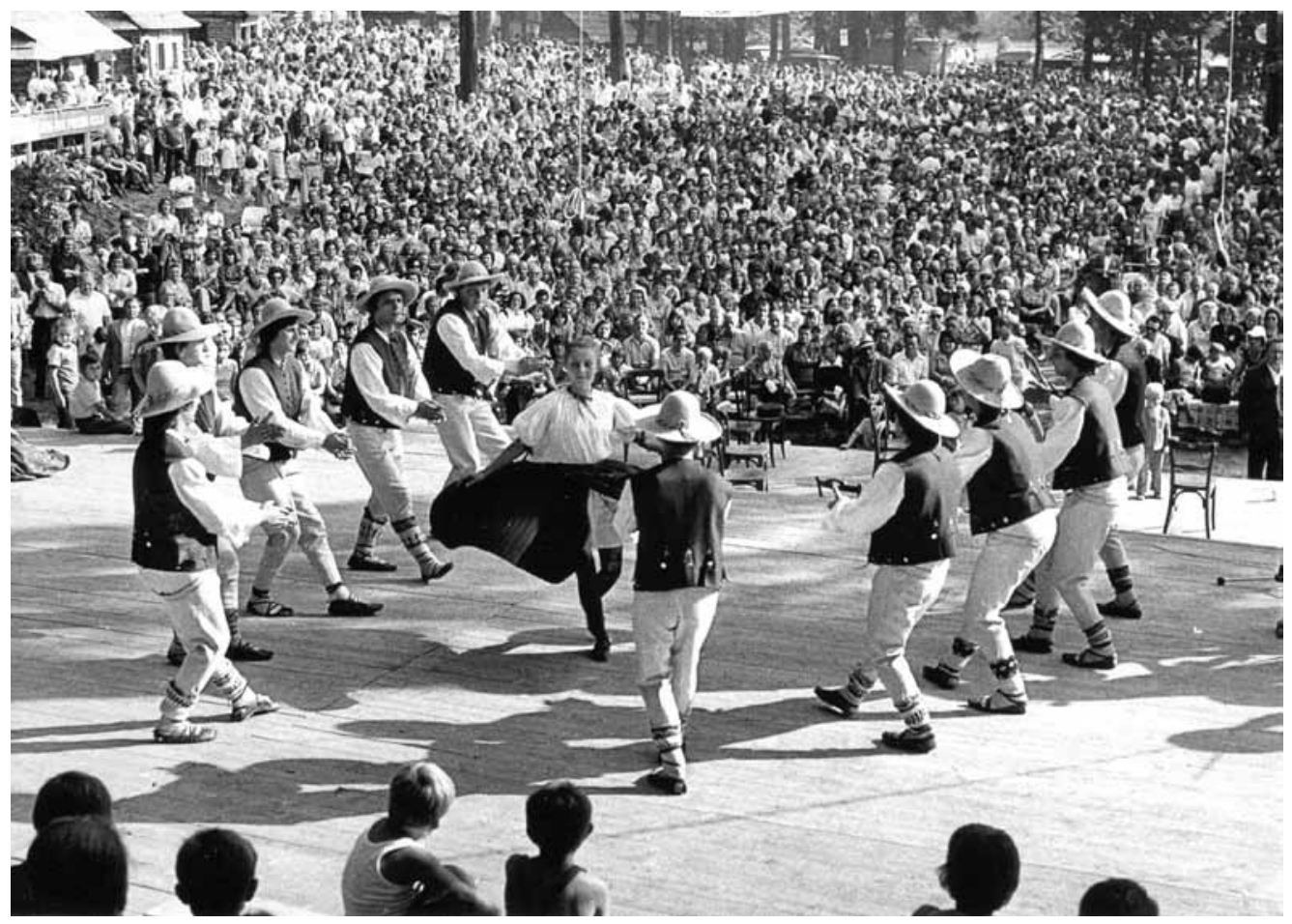


Fot. 8. Gorolski Święto - występ chórów, 15 VIII 1982 r.

\section{ARCHIWUM - AZ PZKO}

NUMER IDENTYFIKACYJNY - sygn. 324a-78a

NAZWA, TYTUŁ - Święto Góralskie

OPIS - Występ połączonych chórów na scenie Lasku Miejskim w Jabłonkowie w ramach Gorolskiego Święta.

SŁOWA KLUCZOWE - Gorolski Święto, Święto Góralskie, Zaolzie, zespoły folklorystyczne TWORZYWO - papier fotograficzny

TECHNIKA- analogowy zapis obrazu

RODZAJ - fotografia analogowa czarno-biała

TWÓRCA - Czesław Góral

MIEJSCE POWSTANIA - Lasek Miejski w Jabłonkowie, miejsce, w którym odbywa się Gorolskie Święto (Czechosłowacja, obecnie Republika Czeska)

CZAS POWSTANIA - 15.8.1982

WYMIARY - [10 x $15 \mathrm{~cm}]$

BIBLIOGRAFIA - brak

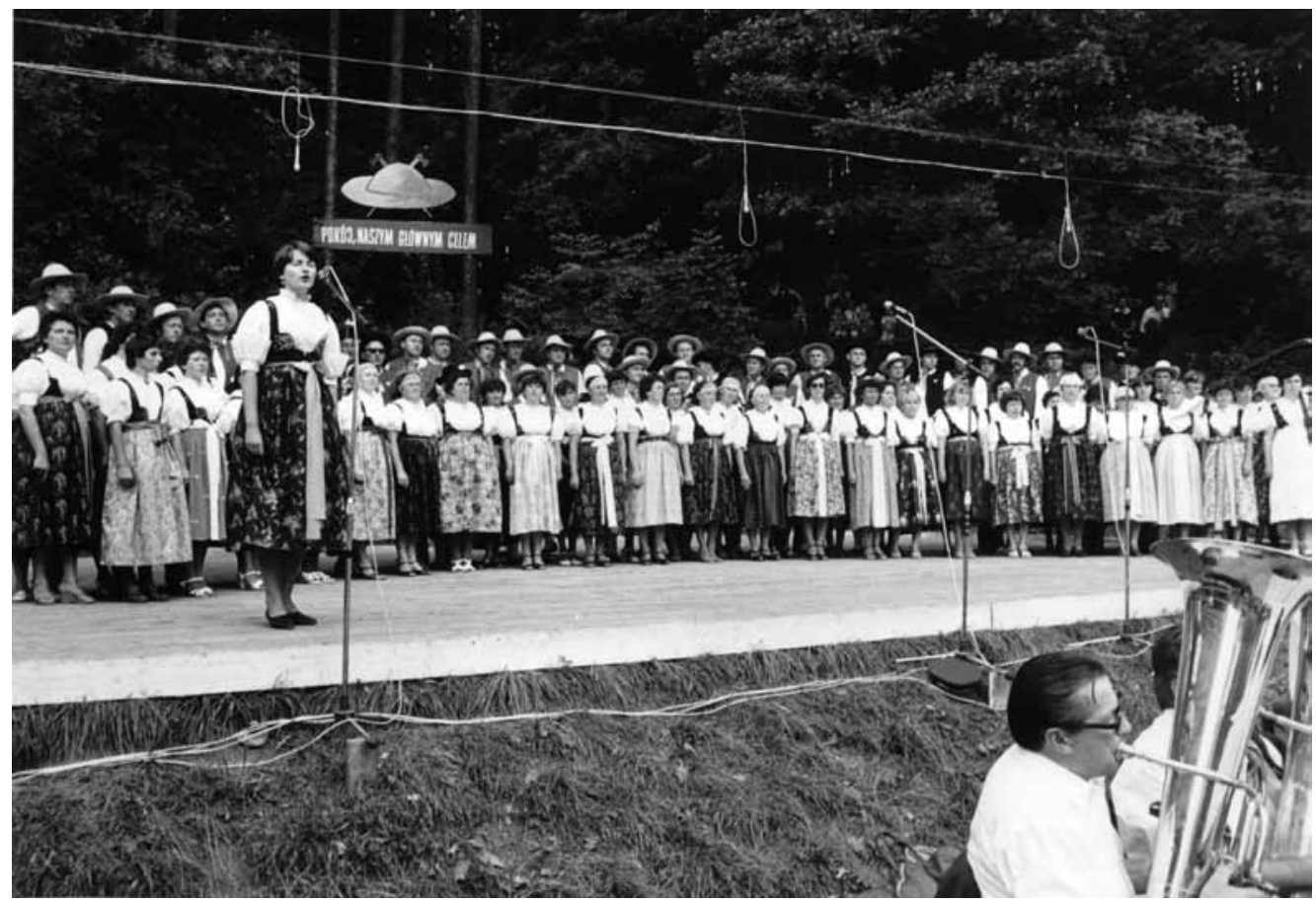




\section{Gorolski Święto w XX w.}

Streszczenie: Artykuł przedstawia pokrótce historię Gorolskiego Święta, ważnego elementu kultury ludowej Śląska Cieszyńskiego. Autorka w niniejszym opracowaniu omawia wystawy towarzyszące imprezie oraz przedstawia postaci od pokoleń związane $\mathrm{z}$ historią tego święta. W dalszej części zamieszczone są zdjęcia tej ważnej dla Polaków imprezy odbywającej się corocznie na Zaolziu.

\section{Gorolski Festival in the 20th Century}

Abstract: The article presents an abridged history of the Gorolski Festival, an important element of the folk culture of Cieszyn Silesia. The author discusses exhibitions accompanying the festival and presents individuals which were connected with the history of the festival for generations. Subsequent sections include photographs of this important Polish event which takes place each year in Zaolzie.

Słowa kluczowe: Gorolski Święto, Święto Góralskie, Zaolzie, zespoły folklorystyczne

Key words: Gorolski Festival, Highland Festival, Zaolzie, folk groups 